\title{
Sodium concentration in germination blotters
}

\author{
D.R. MORGAN AND D.T. BOOTH
}

\begin{abstract}
Walter filtrate from blue germination blotters was analyzed by atomic absorption spectrophotometry and found to contain 509 ug of $\mathrm{Na}^{+} / \mathrm{g}$ of blotter. Since this is a sufficient concentration to confound the results of some studies of seed germination and seedling growth, researchers need to be aware of this potential bias. The findings emphasize the necessity for documenting the quantity of cations present in medium used in germination and seedling growth evaluations.
\end{abstract}

\section{Key Words: germination paper, sodium, research methods}

Seeds of many species are studied each year to determine the optimum conditions for germination and growth. Many of these experiments use some form of absorbent paper for the germination medium. While conducting studies with antelope bitterbrush seeds [Purshia tridentata (Pursh) DC], we detected an unexpected increase of $260 \mathrm{ug} / \mathrm{g}$ in embryo $\mathrm{Na}^{+}$for seeds stratified on steel blue seed germination blotters from Anchor Paper Company, St. Paul, Minnesota ${ }^{1}$. To determine if the blotters were the source of $\mathrm{Na}^{+}$, the $\mathrm{Na}^{+}$concentration was measured in 6 randomly selected blotters from a quantity received in January 1986 . Blotter subsamples (1 g) were soaked in $100 \mathrm{ml}$ deionized water at room temperature for 24 hours. The solution was then filtered through Whatman number 40 filter paper and the filtrate analyzed for $\mathrm{Na}^{+}$by atomic absorption spectrophotometry. Total $\mathrm{Na}^{+}$in the filtrate was divided by the dry weight of the blotter sample and expressed as ug of $\mathrm{Na}^{+}$per $\mathrm{g}$ of blotter paper. The Whatman number 40 filter paper was analyzed by the same procedure. The analysis indicated a $\mathrm{Na}^{+}$ concentration in the blotter paper of $534 \mathrm{ug} / \mathrm{g}(\mathrm{SD}=14.5)$. Sodium in Whatman number 40 paper averaged $25 \mathrm{ug} / \mathrm{g}$ and ranged from 16 to $35 \mathrm{ug} / \mathrm{g}$, resulting in an average of $509 \mathrm{ug} \mathrm{Na}^{+} / \mathrm{g}$ of germination blotter.

The consequences of $\mathrm{Na}^{+}$contamination in germination paper depend upon the experimental methods, the species, and the germination or growth variables being tested. If a two-gram blotter contains $500 \mathrm{ug} \mathrm{Na}{ }^{+} / \mathrm{g}$ blotter and is used with $10 \mathrm{ml}$ of deionized water, the $\mathrm{Na}^{+}$concentration of the imbibed solution would be about $100 \mathrm{ug} / \mathrm{ml}$. If 2 blotters are used with $10 \mathrm{ml}$, and if half of the $10 \mathrm{ml}$ evaporates, the seeds will then have been exposed to a solution concentration that might contain 400 ug Na${ }^{+} / \mathrm{ml}$ of solution. (This is approximate since we do not know how tightly $\mathrm{Na}^{+}$is held by the cellulose fibers of the blotters.)

No effect of blotter $\mathrm{Na}^{+}$on germination or on seedling growth of bitterbrush was detected under conditions similar to the second example above; however, blotter $\mathrm{Na}^{+}$has mitigated the significant $(P \leq 0.05)$ negative influence of polyethylene glycol seed treatments on the growth of mountain mahogany [Cercocarpus montanus (Raf.)] seedlings (Morgan 1988). Studies which have not used blue blotters also provide evidence that $\mathrm{Na}^{+}$can pass through seed integuments to enter the seed. Sharma (1973) presented evidence that $\mathrm{NaCl}$ will enter seeds of Trifolium. Lolium. Danthonia. and

\footnotetext{
Authors are weed agronomist, Hutchinson Pest Control, Pueblo, Colo. 81003; and range scientist, USDA; Agricultural Research Service, High Plains Grasslands Research Station, Cheyenne, Wyo. 82009 . At the time of the research Morgan was graduate research assistant, Plant, Soils, and Insect Sciences Department, University of Wyoming, Laramie.

Manuscript accepted 29 November 1989.
}

Company name and production description are given for information only.
Atriplex and that it will affect the rate and total germination. A concentration of 500 to $1,000 \mathrm{ug} \mathrm{Na}+/ \mathrm{ml}$ of imbibed solution has been found to enhance germination and seedling vigor of winterfat [Eurotia lanata (Pursh) Moq.] (Hilton 1941, Booth 1989, 1990). Similar information has been reported for other chenopods (ElSheikh and Ulrich 1970, Romo and Haferkamp 1987, Eddleman and Romo 1987). The level of $\mathrm{Na}^{+}$found in steel blue seed germination blotters could influence the results of some studies. Therefore when conducting germination and seedling growth research, it can be important to document levels of cations present in the germination medium or in the solution imbibed by the seeds.

\section{Literature Cited}

Booth, D.T. 1989. Seedbed ecology of winterfat: Cations in diaspore bracts and their effect on germination and early plant growth. J. Range Manage. 42:178-182.

Booth, D.T. 1990. Seedbed ecology of winterfat: Effects of mother-plant transpiration wind stress, and nutrition on seedling vigor. J. Range Manage. 43:20-24.

Eddleman, L.E., and J.T. Romo. 1987. Sodium relations in seeds and seedlings of Sarcobatus vermiculatus. Soil Sci. 143:120-123.

El-Sheilh, A.M., and A. Ulrich. 1970. Interactions or rubidium, sodium and potassium on the nutrition of sugar beet plants. Plant Physiol. 46:645-649.

Hilton, J.W. 1941. Effects of certain micro-ecological factors on the germinability and early development of Eurotia lanata. Northwest Sci. 15:86-92.

Morgan, D.R. 1988. Treatment of woody plant seeds to improve germination uniformity and seedling growth. M.S. Thesis. Univ. Wyoming, Laramie.

Romo, J.R., and M.R. Haferkamp. 1987. Forage kochia germination response to temperature, water stress, and specific ions. Agron. J. 79:27-30.

Sharma, M.L. 1973. Simulation of drought and its effect on germination of five pasture species. Agron. J. 65:982-987.

\section{Appendix}

The findings reported in this paper were previously discussed with people at Anchor Paper Company, who then contacted their supplier, James River Corporation, to express concern over the level of $\mathrm{Na}^{+}$in blue germination blotters. James River Corporation explained that in the past, sodium has been added to insure color fastness. They have changed dyes and have advised Anchor Paper Company that as of August 1989, sodium will no longer be added to the germination paper. 